\title{
ENRICHMENT AND ISOLATION OF AEROBIC CHEMOHETEROTROPHIC SPIRILLA FROM MUD AND SAND SAMPLES
}

\author{
YASUKE TERASAKI \\ Biological Laboratory, Suzugamine Women's College, \\ Inokuchi-4-chome, Nishi-ku, Hiroshima 733, Japan
}

(Received August 25, 1980)

\begin{abstract}
Pure culture isolation of aerobic chemoheterotrophic spirilla from mud and sand samples collected from various freshwater and seawater areas in Japan was accomplished by applying the following three methods in the sequence shown: (i) boiled shellfish infusion method for enrichment of spirilla; (ii) glass capillary method for selection of spirilla; and (iii) ordinary streak plate method for pure culture isolation of spirilla. The aerobic spirilla grew well in all enrichment cultures in the 20 experiments performed. Crude cultures containing abundant spirilla were obtained from all enrichment cultures by use of glass capillaries. Pure culture isolation of spirilla from the crude cultures was reliably achieved by the ordinary streak plate method.
\end{abstract}

The putrid infusion of crushed raw shellfish was appropriate for the enrichment of freshwater as well as marine spirilla, and many strains were isolated by direct inoculation onto plates of nutrient agar or nutrient agar using seawater $(1,2)$. Effective enrichment cultures of water spirilla were also obtained by adding the infusion of shellfish prepared by boiling to mud samples collected from freshwater or seawater areas (2), and glass capillaries were also used for the selection of spirilla in that study at the suggestion of Watanabe. Subsequently, the present author found that aerobic chemoheterotrophic spirilla could easily be isolated from mud or sand samples by combining the following three methods in the sequence presented: (i) boiled shellfish infusion method for enrichment of spirilla; (ii) glass capillary method for selection of spirilla; and (iii) ordinary streak plate method for pure culture isolation of spirilla. Then, the present study was carried out to ascertain whether effective enrichment cultures are acquired by chance or the methods are reliable for the enrichment and isolation of aerobic chemoheterotrophic spirilla. This paper deals with the details of the methods and presents the results obtained by applying the methods to mud and sand samples collected from various locations in Japan. 


\section{MATERIALS AND METHODS}

Media. (i) Shellfish infusion medium was prepared as described below. A 10-body amount of freshwater shellfish (Corbicula japonica) was boiled for 4-5 min in $200 \mathrm{ml}$ of freshwater (distilled water) or seawater (drawn at Itsukaichiharbor near Hiroshima City), and the infusion thus obtained was designated as freshwater shellfish-infusion or seawater shellfish-infusion, respectively. After cooling, two or three bodies of the boiled shellfish and an appropriate amount of the infusion were placed in two Petri-dishes, two-thirds of a dish-volume subsequently being occupied with the infusion. The freshwater or seawater infusion was employed for enrichment culture of spirilla living in freshwater or seawater areas, respectively. (ii) Freshwater nutrient broth (NB) containing $5.0 \mathrm{~g}$ of Areipeptone and $3.0 \mathrm{~g}$ of Arei-meat extract (Kyoei Seiyaku \& Co., Ltd., Tokyo) in $1,000 \mathrm{ml}$ of distilled water or seawater nutrient broth (SWNB), with seawater being substituted for the distilled water in NB, was used as growth medium for spirilla obtained from the enrichment cultures, respectively. For plate or stab culture, freshwater nutrient agar (NA) or seawater nutrient agar (SWNA) was employed. The final $\mathrm{pH}$ of the media was adjusted to $7.0-7.2$ using $4 \%$ (w/w) $\mathrm{KOH}$.

Cultures. (i) Enrichment culture was performed as described below. To the infusion medium in each of the Petri-dishes, approximately $5 \mathrm{~g}$ (wet weight) of mud or sand, a habitat of spirilla, was added, and each dish culture was incubated at $20^{\circ}$ or $30^{\circ}$ or allowed to stand at room temperature, separately. When spiral bacteria became luxuriant in the dish enrichment cultures (usually within 3 days), the capillary method was applied to one of the cultures as follows. (ii) For selection of motile spirilla from other bacteria in the enrichment culture, the capillary method was employed. One dozen glass capillary tubes $(60-80 \mathrm{~mm}$ in length, with slender $(0.4 \mathrm{~mm}$ in diameter) and larger ends $(2.0 \mathrm{~mm}$ in diameter $)$ as seen in Fig. 1) were carefully filled with sterilized NB or SWNB avoiding the trapping of air bubbles. By a needle, a small amount of the enrichment culture previously ascertained to be spirilla-rich with a phase-contrast microscope, was inoculated into a meniscus area of the medium from the larger end of the capillary. The motile bacteria inoculated swam in the medium to the slender end. Then, in order

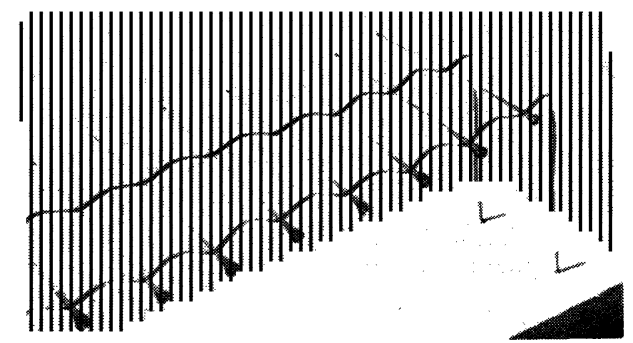

Fig. 1. Glass capillaries arranged side by side on a rack of wire. 
of inoculation, each capillary was cut into small pieces (10-20 mm in length) from the slender end. Each piece was placed into a test-tube containing $10 \mathrm{ml}$ of $\mathrm{NB}$ or SWNB. In each experiment, 50 crude cultures of the test-tube were prepared and incubated at $20^{\circ}$ or $30^{\circ}$, or allowed to stand at room temperature. Growth of spirilla was checked by microscopy after $24-$ or 48 -hr incubation. (iii) Pure culture isolation of the spirilla was readily achieved by streaking the sprilla-dominant crude culture onto plates of NA or SWNA.

Maintenance of stock cultures. The isolates from freshwater materials were preserved as NA stab cultures, while those from seawater materials, as SWNA stab cultures at room temperature $\left(15^{\circ}\right.$ to $\left.33^{\circ}\right)$ with monthly transfers. These isolates were also preserved in lyophil state.

Sources of spirilla. Mud and sand were collected from freshwater and seawater areas of various places in Japan (Fig. 2) and used immediately or within a week as sources of spirilla.

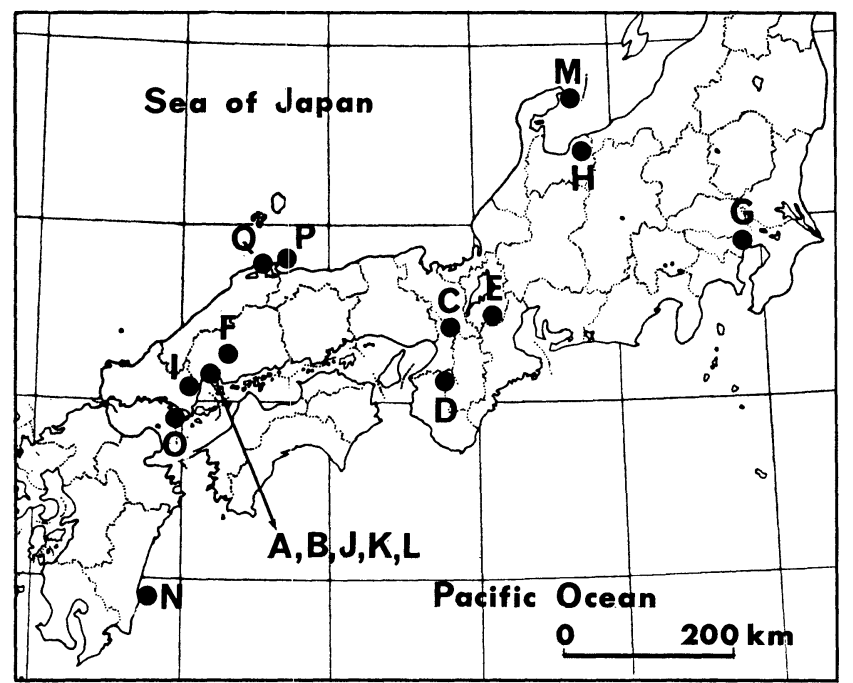

Fig. 2. Locations where mud and sand used for the enrichment of spirilla were sampled. See Table 1 for the geographical name.

\section{RESULTS}

The procedure, consisting of the combination method of the enrichment culture, the capillary method, and the ordinary streak plate method, was applied for isolation of spirilla from 20 samples (muds and sands) collected from freshwater (11 samples) and seawater areas (9 samples) in Japan. The spirilla grew well in all enrichment cultures, although other microorganisms were always in abundance. Almost morphologically uniform spirilla were found in the enrichment cul- 
ture in some cases (Fig. 3), while in other cases various spirilla of shapes and sizes were found. Occasionally, a number of very large spiral bacteria which bore

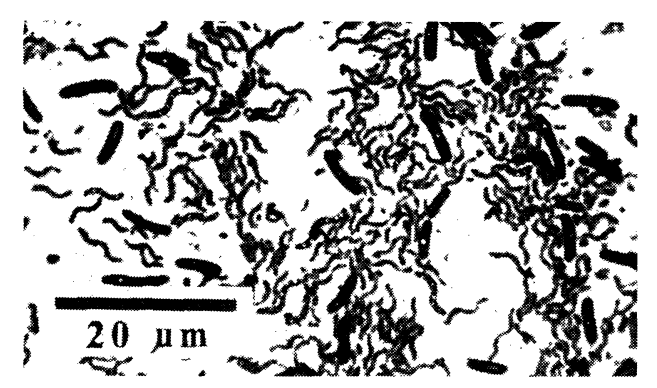

Fig. 3. Organisms taken from a 2-day enrichment culture prepared by adding the freshwater shellish-infusion to mud collected from a freshwater source, stained with a dilute Ziehl-Neelsen's carbolic fuchsin.

Table 1. Enrichment of freshwater and marine spirilla.

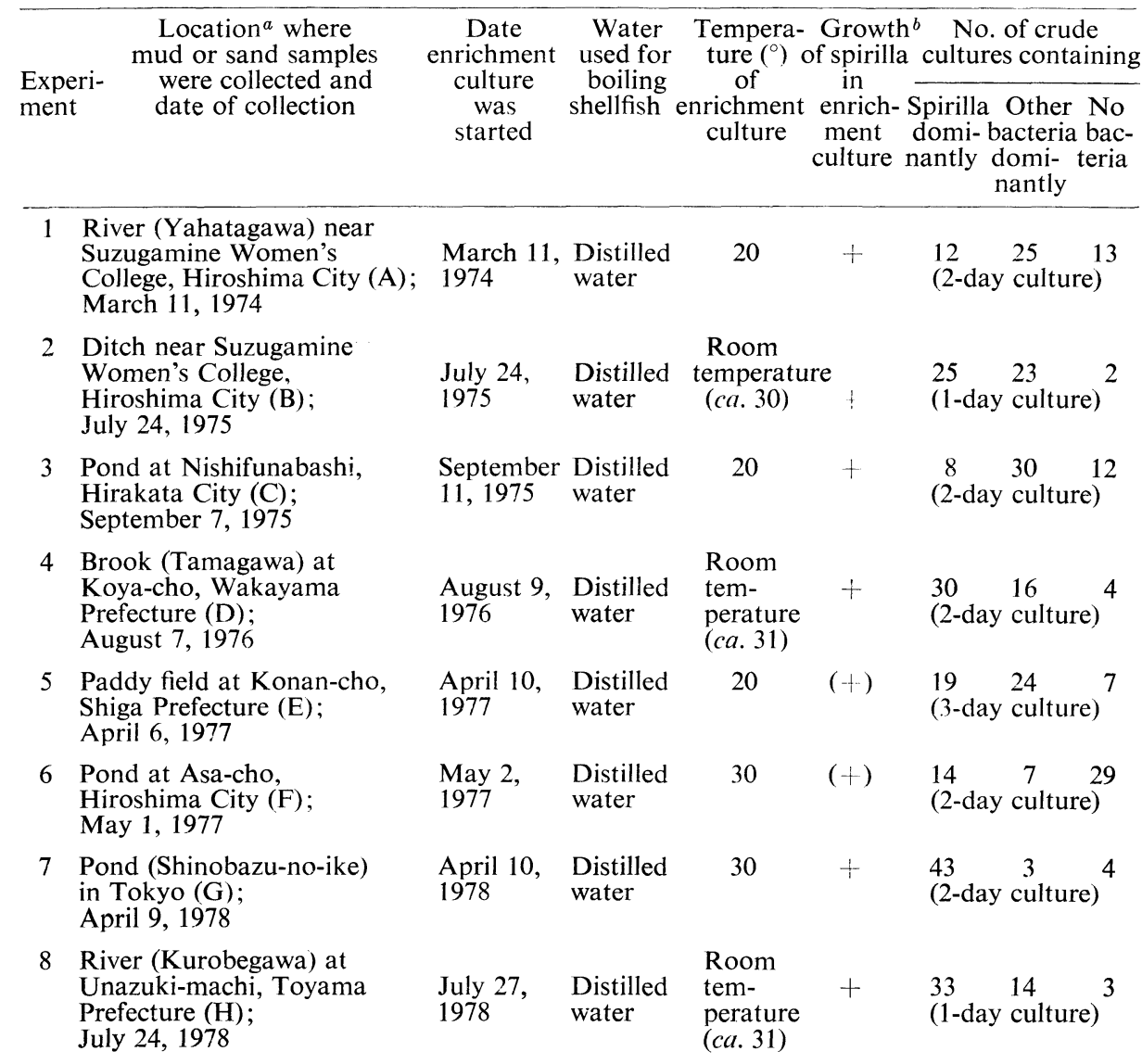


Table 1. (Continued)

\begin{tabular}{|c|c|c|c|c|c|c|}
\hline \multirow{2}{*}{$\begin{array}{l}\text { Experi- } \\
\text { ment }\end{array}$} & \multirow{3}{*}{$\begin{array}{l}\begin{array}{l}\text { Location }^{a} \text { where } \\
\text { mud or sand samples } \\
\text { were collected and } \\
\text { date of collection }\end{array} \\
\text { i- } \\
\text { River (Nishikigawa) near } \\
\text { Kintai Bridge in } \\
\text { Iwakuni City (I); } \\
\text { August 3,1978 }\end{array}$} & \multirow{3}{*}{ 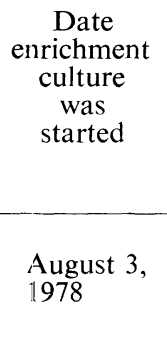 } & \multirow{3}{*}{$\begin{array}{l}\text { Water } \\
\text { used for } \\
\text { boiling } \\
\text { shellfish } \\
\begin{array}{l}\text { Distilled } \\
\text { water }\end{array}\end{array}$} & \multirow{2}{*}{\multicolumn{2}{|c|}{$\begin{array}{l}\text { Tempera- Growth } \\
\text { ture }\left(^{\circ}\right) \text { of spirilla } \\
\text { of in } \\
\text { enrichment enrich- } \\
\text { culture ment } \\
\\
\end{array}$}} & \multirow{2}{*}{$\begin{array}{l}\text { No. of crude } \\
\text { cultures containing } \\
\text { Spirilla Other No } \\
\text { domi- bacteria bac- } \\
\text { nantly domi- teria } \\
\text { nantly }\end{array}$} \\
\hline & & & & & & \\
\hline $\begin{array}{l}\mathrm{R} \\
\mathrm{K} \\
\mathrm{I} \\
\mathrm{A}\end{array}$ & & & & $\begin{array}{l}\text { Room } \\
\text { tem- } \\
\text { perature } \\
(\mathrm{ca} .32)\end{array}$ & + & $\begin{array}{l}22 \\
\text { (1-day culture) }\end{array}$ \\
\hline 10 & $\begin{array}{l}\text { Pond at the campus of } \\
\text { Suzugamine Women's Col- } \\
\text { lege, Hiroshima City }(\mathbf{J}) \text {; } \\
\text { August } 9,1980\end{array}$ & $\begin{array}{l}\text { August } 9 \\
1980\end{array}$ & $\begin{array}{l}\text { Distilled } \\
\text { water }\end{array}$ & $\begin{array}{l}\text { Room } \\
\text { tem- } \\
\text { perature } \\
(\text { ca. 29) }\end{array}$ & + & $\begin{array}{ll}29 & 16 \\
\text { (2-day culture) } & 5\end{array}$ \\
\hline 11 & $\begin{array}{l}\text { The same pond as above; } \\
\text { August } 10,1980\end{array}$ & $\begin{array}{l}\text { August 10, } \\
1980\end{array}$ & $\begin{array}{l}\text { Distilled } \\
\text { water }\end{array}$ & $\begin{array}{l}\text { Room } \\
\text { temperature } \\
\text { (ca. 29) }\end{array}$ & $e^{+}$ & $\begin{array}{l}35 \\
(2 \text {-day culture) }\end{array}$ \\
\hline $\begin{array}{l}\mathrm{B} \\
\mathrm{N} \\
\mathrm{H} \\
\mathrm{S}\end{array}$ & $\begin{array}{l}\text { Beach (Mikasahama) at } \\
\text { Miyajima-cho near } \\
\text { Hiroshima City }(\mathrm{K}) \text {; } \\
\text { September } 13,1970\end{array}$ & $\begin{array}{l}\text { September } \\
14,1970\end{array}$ & Seawater & $\begin{array}{l}\text { Room } \\
\text { tem- } \\
\text { perature } \\
(c a .30)\end{array}$ & + & 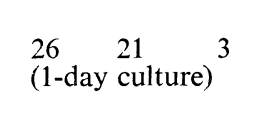 \\
\hline 13 & $\begin{array}{l}\text { Coast at Kairoen, } \\
\text { Itsukaichi-cho near } \\
\text { Hiroshima City (L); } \\
\text { March } 14,1971\end{array}$ & $\begin{array}{l}\text { March } \\
14,1971\end{array}$ & Seawater & 30 & $(+)$ & $\begin{array}{ll}21 & 18 \\
\text { (2-day culture) }\end{array}$ \\
\hline $\begin{array}{l}\mathrm{B} \\
\mathrm{n} \\
\mathrm{P} \\
\mathrm{A}\end{array}$ & $\begin{array}{l}\text { Beach at Koiji, Uchiura- } \\
\text { machi, Ishikawa } \\
\text { Prefecture (M); } \\
\text { August } 12,1977\end{array}$ & $\begin{array}{l}\text { August } \\
15,1977\end{array}$ & Seawater & 30 & $(+)$ & $\begin{array}{l}15 \quad 21 \quad 14 \\
\text { (1-day culture) }\end{array}$ \\
\hline $\begin{array}{l}\text { B } \\
\text { A } \\
\text { C } \\
A\end{array}$ & $\begin{array}{l}\text { Beach near Aoshima, } \\
\text { Aoshima-cho, Miyazaki } \\
\text { City (N); } \\
\text { August } 19,1977\end{array}$ & $\begin{array}{l}\text { August } \\
24,1977\end{array}$ & Seawater & $\begin{array}{l}\text { Room } \\
\text { tem- } \\
\text { perature } \\
(\mathrm{ca} .30)\end{array}$ & + & $\begin{array}{l}26 \\
\text { (1-day culture) }\end{array}$ \\
\hline 16 & $\begin{array}{l}\text { Beach (Nijigahama) } \\
\text { in Hikari City (O); } \\
\text { August } 21,1977\end{array}$ & $\begin{array}{l}\text { August } \\
26,1977\end{array}$ & Seawater & 30 & + & ${ }_{(1-\text { day }}^{4} \begin{array}{l}38 \\
\text { culture })\end{array}$ \\
\hline $\begin{array}{l}\mathrm{C} \\
\mathrm{N} \\
\mathrm{P} \\
\mathrm{C}\end{array}$ & $\begin{array}{l}\text { Coast at Mihonoseki, } \\
\text { Mihonoseki-cho, Shimane } \\
\text { Prefecture (P); } \\
\text { October } 2,1977\end{array}$ & $\begin{array}{l}\text { October } \\
4,1977\end{array}$ & Seawater & 30 & + & $\begin{array}{l}28 \\
(1-\text { day culture })\end{array}$ \\
\hline 18 & $\begin{array}{l}\text { Shore of a salt lake } \\
\text { (Nakaumi) at Nobara-cho, } \\
\text { Matsue City (Q); } \\
\text { October } 3,1977\end{array}$ & $\begin{array}{l}\text { October } \\
9,1977\end{array}$ & Seawater & 30 & + & $\begin{array}{l}31 \quad 1 \quad 18 \\
\text { (1-day culture) }\end{array}$ \\
\hline 19 & $\begin{array}{l}\text { The same coast as in } \\
\text { Experiment } 13 ; \\
\text { August } 11,1980\end{array}$ & $\begin{array}{l}\text { August } \\
11,1980\end{array}$ & Seawater & $\begin{array}{l}\text { Room } \\
\text { temperature } \\
(\text { ca. 29) }\end{array}$ & $e^{+-}$ & $\begin{array}{l}38 \quad 6 \\
\text { (1-day culture) }\end{array}$ \\
\hline 20 & $\begin{array}{l}\text { The same as above; } \\
\text { August } 13,1980\end{array}$ & $\begin{array}{l}\text { August } \\
13,1980\end{array}$ & Seawater & $\begin{array}{l}\text { Room } \\
\text { temperature } \\
(\text { ca. 29) }\end{array}$ & $e^{(+)}$ & $\begin{array}{l}19 \\
(1-\text { day culture })\end{array}$ \\
\hline
\end{tabular}

a The letter given in parentheses represents the location where mud or sand samples were collected. See Fig. 2 for locations.

$b$ Growth: $+=$ such enrichment culture as abundant spirilla were found under a phasecontrast microscope with a low-power objective. $(+)=$ less than + . 
a striking resemblance to Spirillum volutans were found. As can be seen from Table 1, in which the number of spirilla-dominant crude cultures per 50 test-tube cultures prepared from each enrichment culture are listed, the spirilla-dominant crude cultures were obtained with high frequencies from all of the samples tested in this study with the exception of two samples (Experiments 3 and 16). Thus, pure culture isolation of spirilla from the spirilla-dominant crude cultures could be readily achieved by the ordinary streak plate method. When the direct streaking of enrichment culture (in shellfish infusion medium) onto plates of NA or SWNA was occasionally performed with omission of the capillary method, spirillum cultures were also obtained, but the frequencies obtained were low, as presented in Table 2.

\section{DISCUSSION}

The putrid infusion of crushed raw shellfish was used to enrich spirilla in a previous study (l), but it was uncertain as to whether the spirilla growing in the putrid infusion derived from those living in shellfish as parasites or from those temporarily attached to the shellfish. It is deduced from the present study that aerobic chemoheterotrophic spirilla live widely in the mud or sand of various water areas and that they can be enriched, because the shellfish in the enrichment culture medium were previously boiled, and vessels used for the collection of mud or sand had been sterilized. However, it still remains unknown whether they also are living in shellfish as parasites or not.

SCULly and Dondero (3) reported that spirilla were not detectable by microscopy in the freshly collected sample. However, they found that populations of spirilla in 11 samples taken from natural sources were about $4 \%$ (Cladophola), about $0.1-0.6 \%$ (mud, water, slime, trickling filter effluent, and cow manure), and less than $0.01 \%$ (the remainder except hay in which spirilla were not found) of the total bacterial population. From these facts and the general consideration that the isolation of spirilla is difficult, it appears that spirilla only account for a small proportion of the total bacterial population in nature, although they have a wide distribution. In this study, spirilla were hardly detected in the mud or sand samples by direct observation with a phase-contrast microscope. However, they were readily observed in all enrichment cultures. Therefore, it is stated that enrichment of the spirilla can be achieved by the method presented in this paper, although other bacteria are usually in excess and protozoa are frequently found.

The use of capillaries for the isolation of spirilla has already been reported by Giesberger (4), Jannasch (5), and Watanabe (6). Although the details of their respective methods vary, the principle is the same in that spirilla can be separated from nonmotile bacteria due to their high motility. It is uncertain whether the capillary method described in this paper is more convenient than their methods be- 
Table 2. Effectiveness of the capillary method for isolation of spirilla.

\begin{tabular}{|c|c|c|c|c|}
\hline \multirow{2}{*}{ Experiment $^{a}$} & \multicolumn{2}{|c|}{ No. of } & \multicolumn{2}{|c|}{$\begin{array}{l}\text { Rate }(\%) \text { of spirillum } \\
\text { cultures to the total number } \\
\text { of bacterial cultures }\end{array}$} \\
\hline & $\begin{array}{l}\text { Spirilla-dominant } \\
\text { crude cultures } \\
\text { prepared by the } \\
\text { capillary method }{ }^{b}\end{array}$ & $\begin{array}{l}\text { Bacterial cultures } \\
\text { isolated by streak } \\
\text { plate method with- } \\
\text { out capillaries }^{c}\end{array}$ & $\begin{array}{l}\text { Capillary } \\
\text { method }\end{array}$ & $\begin{array}{l}\text { Streak plate } \\
\text { method without } \\
\text { capillaries }\end{array}$ \\
\hline 2 & 25 & $2 / 12$ & 50 & 17 \\
\hline 10 & 29 & $\begin{array}{l}2 / 10 \\
0 / 22\end{array}$ & 58 & $\begin{array}{r}20 \\
0\end{array}$ \\
\hline 11 & 35 & $\begin{array}{l}1 / 14 \\
0 / 10\end{array}$ & 70 & $\begin{array}{l}7 \\
0\end{array}$ \\
\hline 12 & 26 & $\begin{array}{l}1 / 4 \\
2 / 13\end{array}$ & 52 & $\begin{array}{l}25 \\
15\end{array}$ \\
\hline 19 & 38 & $\begin{array}{l}1 / 17 \\
1 / 10\end{array}$ & 76 & $\begin{array}{r}6 \\
10\end{array}$ \\
\hline 20 & 19 & $0 / 20$ & 38 & 0 \\
\hline
\end{tabular}

a Numerals indicate the same experimental number as described in Table 1.

$b$ Numerals indicate the number of spirilla-dominant crude cultures in 50 cultures of the test-tube (See MATERIALS AND METHODS).

$c$ Numerators indicate the number of spirillum cultures, and denominators indicate the total number of bacterial cultures from one plate. For the isolation, one or two appropriate plates were chosen from among 5 plates which had been inoculated by successive strokes with a wire loop charged with a small amount of enrichment culture in each experiment.

cause the present author did not apply them.

Previously, spirilla were isolated on agar plates inoculated directly with the enrichment culture (1), but not all of the plates were available for the current isolation. In most cases, spirilla could be obtained from small or pinpoint colonies among a crowd of colonies of other bacteria. Sometimes, other bacteria grew readily and covered the surface of plates prior to colony formation of spirilla. On the other hand, almost all spirillum cultures can easily be obtained from the colonies grown by streaking spirilla-dominant crude cultures prepared by the capillary method. Table 2 shows the effectiveness of the capillary method compared with that of the streak plate method without capillaries. Thus, it can be concluded that the capillary method employed here is very effective for isolation of freshwater as well as marine spirilla. WiLliams and RitTEnBERG (7) reported that isolations direct from algal infusions had been readily accomplished but were not successful from the initial enrichment cultures with a peptone-yeast autolysate medium because of the large excess of other bacteria. They also obtained a good enrichment culture of spirilla by the troublesome procedure whereby the mixture of the initial enrichment culture and the source water was sterilized, and the resulting solution was inoculated from the unsterilized portion of the initial culture. The reliability and availability of the combination method mentioned in this paper are applicable to either freshwater spirilla or marine spirilla so long as they are aerobic and 
chemoheterotrophic. In addition to the confirmation, the present study indicates that the method may possibly be effective for the isolation of many kinds of spirilla because it is applicable to mud and sand samples taken from various water areas.

S. volutans-like spirilla grown occasionally in the enrichment cultures could not be isolated, nevertheless they were evident in several crude cultures. WiLLIAMS and RitTENBERG (7) observed such spirilla in malate enrichment and attempted to grow them by the use of Pringsheim soil infusion medium, but they could not isolate in pure culture. Since Wells and KRIEG (8) isolated a strain of $S$. volutans from a pond water-hay infusion using the Rittenberg method (9) and succeeded in culturing it in a bacteria-free environment for the first time by their peculiar method, it is considered that a favorable method for the enrichment and isolation of microaerophilic spirilla may be devised by modifying the methods described in this paper.

The temperature of the enrichment cultures was $20^{\circ}, 30^{\circ}$ or room temperature in the present study because the mud and sand samples were collected from places where the temperature was regarded to be appropriate for the growth of mesophilic bacteria. If the mud or sand samples are taken from such places inhabited by thermophilic or psychrophilic bacteria, and enrichment cultures are prepared under conditions suitable for their growth, thermophilic or psychrophilic spirilla should grow in such cultures.

The author wishes to thank Dr. N. Watanabe, former professor, Chiba University, for his kindness in suggesting the use of glass capillaries for the selection of spirilla and Dr. S. Fukui, Institute of Applied Microbiology, University of Tokyo, for his kind reading of the manuscript. $\mathrm{He}$ is also indebted to Miss K. Sugioka and Miss N. Yamasaki, Suzugamine Women's College, for their assistance in collecting mud or sand samples.

\section{REFERENCES}

1) Y. Terasaki, Bull. Suzugamine Women's Coll. Nat. Sci., 10, 1 (1963).

2) Y. Terasaki, Bull. Suzugamine Women's Coll. Nat. Sci., 15, 1 (1970).

3) D. A. Scully and N. C. Dondero, Can. J. Microbiol., 19, 983 (1973).

4) G. Giesberger, Dissertation, Delft (1936), p. 39.

5) H. W. Jannasch, Zentralbl. Bakteriol. Parasitenkd. Infektionskr. Hyg., I. Abt. Suppl. 1, 198 (1965).

6) N. Watanabe, Bull. Fac. Educ., Chiba Univ., 18, 212 (1969).

7) M. A. Williams and S. C. Rittenberg, Int. Bull. Bacteriol. Nomencl. Taxon., 7, 49 (1957).

8) J. S. Wells, Jr. and N. R. KRIEG, J. Bacteriol., 90, 817 (1965).

9) B. T. Rittenberg and S. C. Rittenberg, Arch. Mikrobiol., 42, 138 (1962). 